\title{
REGIOSELECTIVITY ENHANCEMENT BY PARTIAL PURIFICATION OF LIPASE FROM ASPERGILLUS NIGER
}

\author{
Hao-Ping Chen, ${ }^{1}$ Kwo-Feng Hsiao, ${ }^{2}$ Shih-Hsiung $\mathrm{Wu}^{* 3}$ and \\ Kung-Tsung Wang 2,3
}

\author{
1Department of Biochemistry, China Medical College, Taichung, Taiwan \\ 2Department of Chemistry, National Taiwan University, Taipei, Taiwan \\ 3Institute of Biological Chemistry, Academia Sinica, Taipei, Taiwan
}

Lipase from Aspergillus niger was partially purified by a single step of ionexchange chromatography and two major fractions I and II could be obtained. Two substrates, peracetylated 1-methyl and 1-thioethyl $\beta$-D-glucopyranosides, were deacetylated by fraction II to give $3-\mathrm{OH}$ derivatives as sole products with very high yield, respectively.

\section{Introduction}

Lipase has been widely used to regioselective deacylation in carbohydrates, steroids and glycols. ${ }^{1}$ As we are aware, partially acetylated monosaccharides are important in many respects, such as chiral building blocks in synthesis ${ }^{2}$ and versatile intermediates in preparation of oligosaccharides and O-substituted derivatives. ${ }^{3}$ In addition, they are also used as reference compounds for the analysis of polysaccharides. ${ }^{4}$ Crude lipase from Aspergillus niger, as infered by others, ${ }^{5}$ can acylate and deacylate monosaccharide on primary position with high yieds.

According to the previous report, ${ }^{6}$ cleaving the secondary esters, not primary ones, of peracetylated 1-methyl glycopyranosides is a notable character of Aspergillus niger lipase. However, the products were mixed with $2-\mathrm{OH}, 3-\mathrm{OH}$ and 4-OH derivatives when compound 1-5 were used as substrates. In order to increase regioselectivity, the crude enzyme was simply purified by a single step of ion-exchange column and two major fractions I and II, which showed hydrolytic activity toward peracetylated 1-methyl glycopyranosides, were obtained. Fraction II which possesses much higher activity than fraction $I$ is the major component in crude lipase. Five peracetylated 1-methyl glycopyranosides and one peracetylated 1-thioethyl $\beta$-D-glucopyranosides were hydrolyzed by fraction II, Scheme 1 and the results were shown in talble 1. 


\section{Experimental}

Enzyme Purification: The crude lipase AP-6 was purchaised from Amano Company, Japan. Dissolved $0.45 \mathrm{~g}$ in $0.7 \mathrm{ml} 10 \mathrm{mM}$ Tris Buffer $(\mathrm{pH}=7)$ was applied to TSK-DEAE 650 open column (1.5 x $35 \mathrm{~cm})$, pre-equilibrated in $10 \mathrm{mM}$ Tris Buffer ( $\mathrm{pH=7}$ ) containing $3 \mathrm{mM}$ $\mathrm{CaCl}_{2}$. Ion-exchange chromatography was carried out in following steps: (A) elution with $150 \mathrm{ml} 10 \mathrm{mM}$ Tris buffer ( $\mathrm{pH}=7$ ) containing $3 \mathrm{mM} \mathrm{CaCl}_{2}$. (B) elution with $400 \mathrm{ml} 10 \mathrm{mM}$ Tris buffer containing $80 \mathrm{mM} \mathrm{NaCl}$ to wash out unwanted component. (C) elution with 500 $\mathrm{ml} 10 \mathrm{mM}$ Tris buffer containing $100 \mathrm{mM} \mathrm{NaCl}$. The flow rate was adjusted to $1 \mathrm{ml} / \mathrm{min}$ and the eluates were collected by the fraction collector, about $8 \mathrm{ml}$ per tube.

Pool the fraction I possessing lipase activity eluted in step (A) and fraction II in step (C). Before pooling fraction II together, to assay regioselectivity toward peracetylated 1-methyl $\beta$ $D$-glucopyranoside in each tube is essential. Devide each fraction into 3 parts. Then, dialysis against dist $\mathrm{H}_{2} \mathrm{O}$ (MW 1000 membrane) overnight and lyophilize separatly.

Reaction Condition of Fraction II: Each part of lyophilized fraction was dissolved in $6 \mathrm{ml}$ of $0.1 \mathrm{M}$ phosphate buffer ( $\mathrm{pH}=7$ ), then $0.1 \mathrm{~g}$ substrates were added. All substrates must be crushed into fine powder before addition. The deacylation reaction was progressing with shaking $(150 \mathrm{rpm})$ at $30^{\circ} \mathrm{C}$ without $\mathrm{pH}$ adjustment.

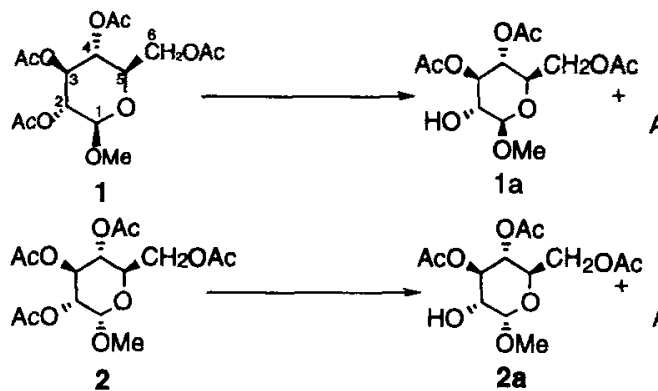

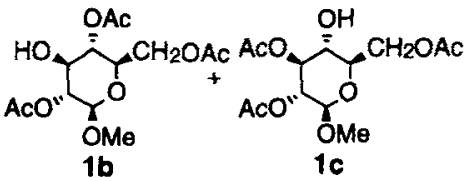

1b

$1 \mathrm{c}$

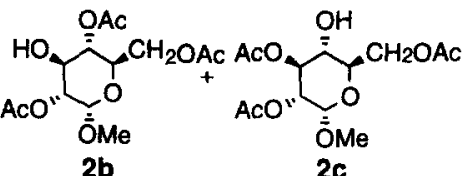

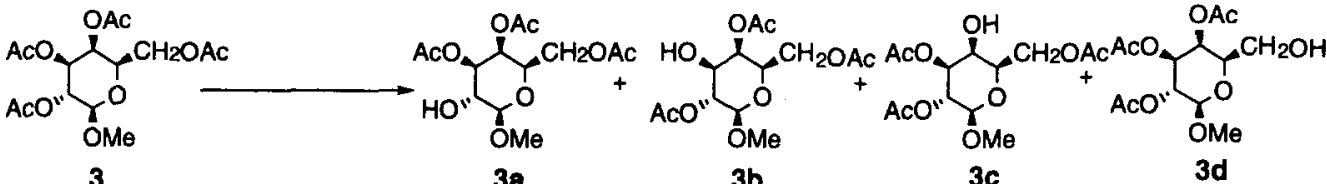

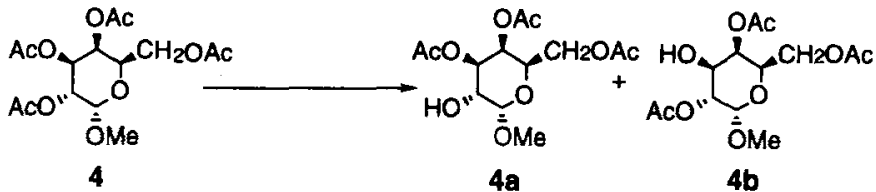

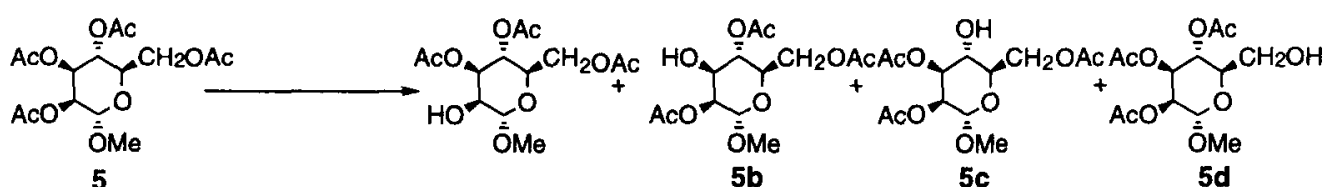

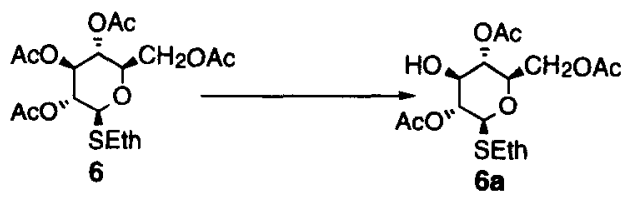

Scheme 1. 
Product Collection and Analysis: The deacylation reaction was stopped by extraction with EtOAc four times. The products and substrates were obtained after purification by a silica gel open column. The unreacted substrate and product, triacetates, can be seprated with ether: $n$ Hexane $=3: 2$ and ether: $n$-Hexane $=4: 1$ as eluent respectly.

The conversion and yield could be calculated after dried and weighted. A reversed-HPLC (C18 column, $4.6 \mathrm{~mm} \times 300 \mathrm{~mm}$ ) was also used to determine the ratio of different kind of triacetate with $\mathrm{H}_{2} \mathrm{O}$ : acetonitrile $=80: 20$ as the mobile phase at a flow-rate of $1 \mathrm{ml} / \mathrm{min}$. All the structures of the products were determined from the $2 \mathrm{D}{ }^{1} \mathrm{H}-1{ }^{1} \mathrm{H}$ COSY as well as $2 \mathrm{D}{ }^{1} \mathrm{H}$ $-{ }^{13} \mathrm{C}$ COSY NMR spectra.

\section{Results and Discussions}

Peracetylated 1-methyl $\beta, \alpha-D$-glucopyranosides (1 and 2) and peracetylated 1thioethyl $\beta$-D-glucopyranosides (6) were fast hydrolyzed by Fraction II with high yield. The 3-OH derivatives of compound 1 and 6 were produced as sole products; meanwhile, the 3$\mathrm{OH}$ derivatives of compound 2 were produced as major products. Compared with the crude enzyme, fraction II had much higher regioselectivity toward 1 and 2 . For other substrates (3, 4 and 5), fraction II also shows higher regioselectivity than the crude enzyme.

Table 1. Deacylation of Compound 1-6 by Fraction II

\begin{tabular}{|c|c|c|c|c|}
\hline Compound & $\begin{array}{l}\text { Reaction } \\
\text { Time (hr) }\end{array}$ & $\begin{array}{l}\text { Conversion of } \\
\text { Substrates }\end{array}$ & $\begin{array}{l}\text { Yields of } \\
\text { Triacetates }\end{array}$ & Ratio of Different Triacetates \\
\hline $\mathbf{1}$ & 2.5 & $100 \%$ & $84.3 \%$ & $\begin{array}{l}\mathbf{1 b} \\
>98 \%\end{array}$ \\
\hline 2 & 2.5 & $100 \%$ & $93.6 \%$ & $\begin{array}{l}\mathbf{2 b}: \mathbf{2 c} \\
=93 \%: 7 \%\end{array}$ \\
\hline 3 & 2.5 & $55 \%$ & $85.4 \%$ & $\begin{array}{l}\text { 3a : 3b : 3c : 3d } \\
=17.2 \%: 46.2 \%: 20.4 \%: 16.2 \%\end{array}$ \\
\hline 4 & 4 & $48 \%$ & $82.1 \%$ & $\begin{array}{l}\mathbf{4 a}: \mathbf{4 b} \\
=77.1 \%: 22.9 \%\end{array}$ \\
\hline 5 & 2.5 & $68 \%$ & $52.9 \%$ & $\begin{array}{l}\mathbf{5 a}: \mathbf{5 b}: \mathbf{5 c}: \mathbf{5 d} \\
=76.7 \%: 3 \%: 3 \%: 17.3 \%\end{array}$ \\
\hline 6 & 2.5 & $95 \%$ & $82.2 \%$ & $\begin{array}{l}6 \mathbf{a} \\
>98 \%\end{array}$ \\
\hline
\end{tabular}

Although diacetoneglucose which possesses 3-OH and acid-labile protecting group is easily prepared or commercially available, the two $3-\mathrm{OH}$ derivatives $(\mathbf{1} \mathbf{b}$ and $\mathbf{2 b}$ ) which possess base-labile protecting group may give an alternative way to use monosaccharides derivatives as starting material in organic and carbohydrate chemistry. In addition, the product of compound $6 \mathbf{a}$ can be provided as a useful donor in oligosaccharide synthesis. 
In the previous reports, Candida lipase (Candida cylindracea) exclusively cleaved the primary ester of peracetyl 1-methyl glucopyranoside to form 6-OH derivatives as sole product in phosphate buffer. ${ }^{7,8}$ It means that $4-->6$ or $3->6$ acetyl migration hardly occur in phosphate buffer. Therefore, the formation of $\mathbf{1 b}$ and $\mathbf{2 b}$ through the cleavage of 6-acetyl group and then $3 \rightarrow 6$ acetyl migration in phosphate buffer has been ruled out.

The partial purified A.niger lipase, fraction II, in phosphate buffer can be recovered and reused, at least five times, even after extraction with EtOAc, dialysis against pure water and lyophilization and still maintain good reactivity and regioselectivity. The lyophilized powder can be sotred at $4^{\circ} \mathrm{C}$ for a long time. This method is well established in our lab and can be easily expanded to $5 \mathrm{~g}$ scale in preparation of compund $\mathbf{1 b}$ and $\mathbf{6 a}$.

\section{References}

1. (a)Faber,K., Riva, S.Synthesis, 1992,895. (b)Boland. W, Frobl, C.Lorenz, M.Synthesis, 991, 1048. (c)Chen, C.S., Sih, C.J. Angew.Chem. Int. Eng. Ed. 1989, 28, 695.

2. (a)Cintas, P. Tetrahedron, 1991, 47, 6079.(b) Hanessian, S. Total Synthesis of Natural Products: The Chiron Approach, Pergamon, Oxford, 1983.

3. (a)Haines, A.H. Adv. Carbohydr. Chem. Biochem., 1976, 33, 11.(b) Haines, A.H. Adv. Carbohydr. Chem. Biochem., 1981, 39, 13.

4. Aspinall, G.O. in G.O. Aspinall (Ed.), in Int. Rev. Sci.,Org. Chem. Ser. Two,Butterworths, London, 1976, 7, 201.

5. (a)Holla, W. Angew. Chem. Int. Ed. Engl. 1989, 28, 220.(b)Therisod, M., Klibanov, A. M.J. Am. Chem. Soc. 1987, 109, 3977.(c)Hene, W.J.,Sweers, H.M.,Wang, Y.F.,Wong, C.H. J.Org. Chem. 1988, 52, 4939. (d)Shaw, J.F.,Klibanov, A.M. Biotecnol. Bioeng. 1987, 29, 648 .

6. Hsiao, K.F., Wu, S.H., Wang, K.T. BioMed Chem. Lett. 1993, 3, 2125.

7. Sweers, H.M., Wong, C.H., J. Am. Chem. Soc. 1986, 108, 6421.

8. Hennen, W. J; Sweers, H. M; Wang, Y. F. and Wong, C. H. J. Org. Chem.. 1988, 53, 4939. 